

\title{
The combining ability of lucerne clones resistant to "alfalfa sickness"
}

Felicitas M. Katepa, P. Nagarajan, Peter D. Walton

\section{To cite this version:}

Felicitas M. Katepa, P. Nagarajan, Peter D. Walton. The combining ability of lucerne clones resistant to "alfalfa sickness". Agronomie, 1986, 6 (10), pp.893-896. hal-00884836

\section{HAL Id: hal-00884836 \\ https://hal.science/hal-00884836}

Submitted on 1 Jan 1986

HAL is a multi-disciplinary open access archive for the deposit and dissemination of scientific research documents, whether they are published or not. The documents may come from teaching and research institutions in France or abroad, or from public or private research centers.
L'archive ouverte pluridisciplinaire HAL, est destinée au dépôt et à la diffusion de documents scientifiques de niveau recherche, publiés ou non, émanant des établissements d'enseignement et de recherche français ou étrangers, des laboratoires publics ou privés. 


\title{
The combining ability of lucerne clones resis- tant to "alfalfa sickness",
}

\author{
Felicitas M. KATEPA*, P. NAGARAJAN $\left({ }^{2}\right)$, Peter D. WALTON* ${ }^{(1)}$ \\ (*) Department of Plant Science, University of Alberta, Edmonton, Alberta, Canada T6G 2P5
}

\begin{abstract}
Diallel crosses of nine clones of Medicago media Pers. previously selected for resistance to "alfalfa sickness" were grown in a field trial and in the greenhouse. Dry matter yield, plant height, leaf area, leaf dry weight and root necrosis were recorded. These data show that three previous cycles of recurrent selection for increased height, low root necrosis and high yield had substantially reduced additive genetic components of variation for all the traits studied having an influence on resistance. Further advances in selecting for disease resistance cannot be expected until "alfalfa-sickness" has been clearly defined, the causal organism isolated and additional sources of genetic variation for disease resistance become available.
\end{abstract}

Additional key words : Diallel cross, disease resistance, leaf area, leaf weight, general combining ability, additive gene action.

Des croisements diallèles de neuf clones de Medicago media Pers. préalablement sélectionnés pour leur résistance à l'" alfalfa sickness" sont élevés dans des essais au champ et en serre. Les poids sec, hauteur des plantes, surface foliaire, poids sec des feuilles et nécroses racinaires sont notés. Ces données démontrent que 3 cycles de sélection récurrente vis-à-vis de l'accroissement de la hauteur, des nécroses racinaires réduites et d'un rendement élevé ont substantiellement réduit les composants génétiques additifs de la variation pour tous les caractères étudiés influant sur la résistance. Tant que le syndrome de l'" alfalfa sickness » et que la cause ne sont pas bien définis, et que l'on ne connaît pas de sources supplémentaires de variabilité génétique pour la résistance, il ne faut pas s'attendre à des progrès déterminants pour la sélection.

Mots clés additionnels : Croisement diallèle, résistance à la maladie, surface foliaire, poids foliaire, aptitude générale à la combinaison, action de gènes additifs.

\section{INTRODUCTION}

"Alfalfa sickness" is a specific condition of poor seedling growth of lucerne found when successive crops are grown on the same land. The "sick" plants are stunted and spindly with yellowish leaves which bear irregular necrotic patches. The lateral roots develop brown lesions and become girdled (fig. 1) leading to the collapse of the young plants (DAMIRGI et al., 1976, 1978 and 1979). The root nodules are either absent or appear in large whitish clumps. The disease was first observed in 1962 on light textured soils but only in fields which previously contained lucerne. The fields show characteristic irregular patches of healthy and diseased growth (GOPLEN \&

(1) University of Zambia, Lusaka, Zambie.

(2) Alberta Research Council, Canada.
WEBSTER, 1969). Investigative studies by WEBSTER et al. (1967) determined that the sickness is not caused by a deficiency or excess of soil micro and macro mineral nutrients, and soil moisture. Furthermore, the sickness is not related to nematodes (WEBSTER \& HAWN, 1973 ; DAMIRJI et al., 1976). Soil sterilization, using either steam or chemicals, eliminates the sickness leading to the conclusion that the primary cause of "alfalfa sickness" is biological in nature. Various fungi including Phytophthora megasperma, Fusarium, Pythium, and Cylindrocarpon species have been implicated. Upon testing, $P$. megasperma produced disease symptoms very similar to "alfalfa sickness", but $P$. megasperma has not been consistently isolated from lesions on roots of sick plants. Furthermore, $P$. megasperma infection is known to be most prevalent in heavy, poorly drained soils, a category into which the "alfalfa sick" soils do not 

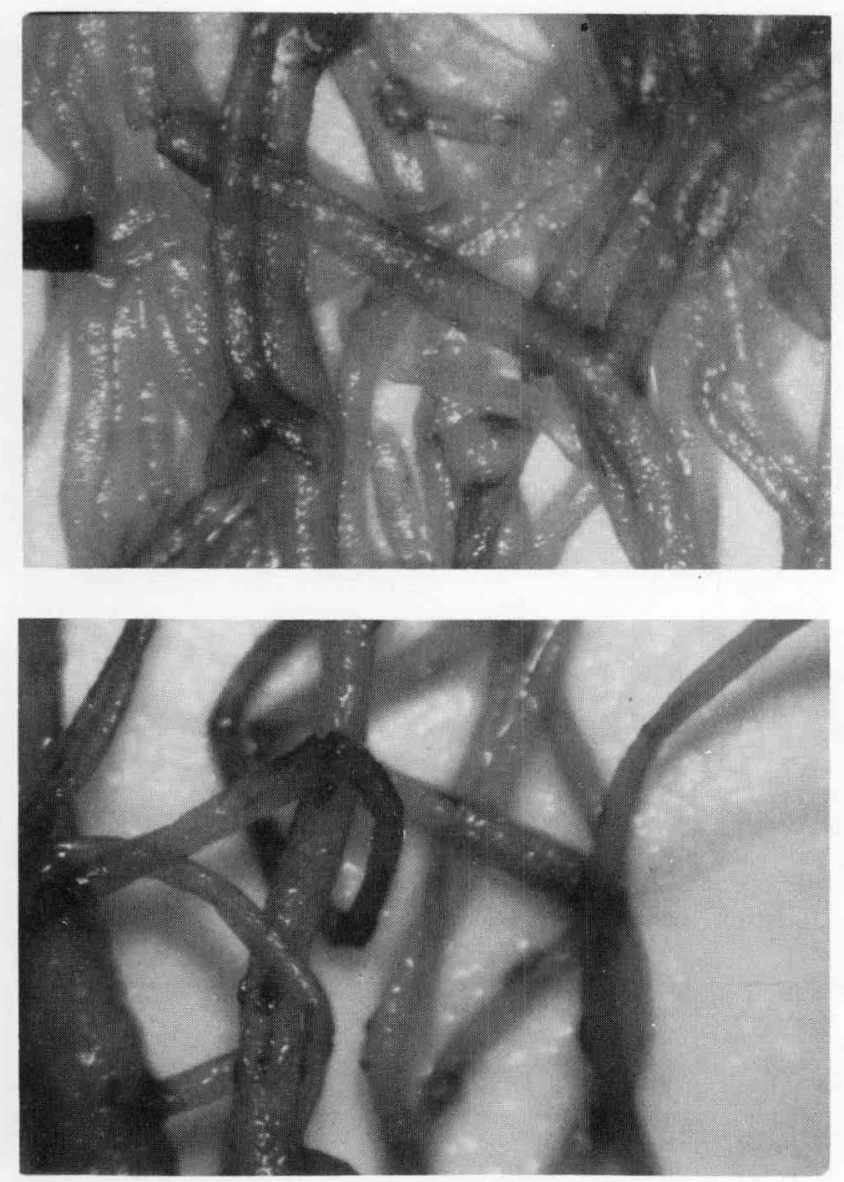

Figure 1

Roots of M. media showing necrotic lesions which girdle the secondary roots.

Racines de M. media démontrant des lésions nécrotiques qui entourent les racines secondaires.

fit. Thus, there remains a need to determine the causal factor of "alfalfa sickness".

While the causal organism has not been identified with certainty it is still possible to select for resistance by growing young seedlings in diseased soil. FAECHNER \& BOLTON (1978) demonstrated increased resistance to the sickness as a result of selections made in this way. After three cycles of recurrent selection they obtained a $14 \%$ reduction in root necrosis and a $39 \%$ increase in plant height which contributed to an $80 \%$ increase in dry matter yield. The selections made in the glasshouse and based on plant phenotypic traits, culminated in the development of six synthetic strains, four of which are being tested for commercial use in seed and dry matter yield trials. Present research aims at improving the selection criteria and crossing strategy in this lucerne breeding programme, by examining the field performance and gene action of clones previously selected for their phenotypic reaction to "alfalfa sickness".

\section{MATERIALS AND METHODS}

The diallel cross analysis developed by JINKS \& HAYMAN (1953) has been employed to provide estimates of the genetic components of variation. GRIFFING (1956) employs the general and specific combining abilities of parental lines to estimate the additive and non-additive components of genetic variation since :

$\sigma_{\mathrm{a}}^{2}=2 \sigma_{\mathrm{g}}^{2}$ and $\sigma_{\mathrm{na}}^{2}=\sigma_{\mathrm{s}}^{2}$

where

$\sigma_{\mathrm{a}}^{2}=$ additive genetic variance
$\sigma_{\mathrm{na}}^{2}=$ non-additive variance
$\sigma_{\mathrm{g}}^{2}=$ general combining ability variance
$\sigma_{\mathrm{s}}^{2}=$ specific combining ability variance

GRIFFING's analysis also enables the estimation of reciprocal and maternal effects. In the present study, the experimental material is autotetraploid and does not meet the necessary assumption of homozygosity therefore preventing a precise measure of the components of genetic variation. It is possible to allude the relative importance of additive and non-additive genetic variation in the system.

The study involved two diallel crosses, one in the field and the other in the glasshouse. They contained progenies of nine lucerne clones of $M$. media, which were previously selected for increased height, low root necrosis and high dry matter yield when grown in "alfalfa sick" soil. These clones were selected from a diverse population derived from the cultivars ROAMER, GRIMM, VERNAL \& BEAVER. The individual clones are not related (table 3 ). The field diallel contained both $F_{1}$ crosses and reciprocals for the nine clones and was sown in 1983 on a black chernozem silty clay loam at the University farm in Edmonton.

The seeds were scarified with sand paper and germinated on moist filter paper in petri dishes at room temperature. At a radicle length of 0.5 to $1 \mathrm{~cm}$, the germinated seed was inoculated with a commercial culture of Rhizobium meliloti and planted in individual root trainers. The seedlings were grown in the glasshouse at $18^{\circ} \mathrm{C}$ under natural lighting then cut back to a height of $10 \mathrm{~cm}$ from the soil and hardened in the sun prior to planting in the field. One litre of a starter solution (NPK in the ratio of 10-52-10) was applied to each plant at planting. The experimental design was a randomized block with six replications and six plants per plot. Yield data were obtained from one cut in the 1983 and two in 1984 growing seasons. The harvest from each plot was placed in a cloth bag and dried at $35-40{ }^{\circ} \mathrm{C}$.

In the glasshouse, a half diallel without the parental lines was established on a light textured chernozem soil known to cause "alfalfa sickness". The soil was collected from several random locations within a "sick" field to a depth of $15 \mathrm{~cm}$, mixed and sieved through a $0.6 \mathrm{~cm}$ wire mesh screen, and stored at $4{ }^{\circ} \mathrm{C}$ prior to use. Six replications of four plants of each of the thirty-six crosses were grown in $13 \mathrm{~cm}$ plastic pots for 35 to 42 days at a temperature of $18{ }^{\circ} \mathrm{C}$ under natural daylight. The seedlings were then evaluated for plant height $(\mathrm{cm})$, leaf area $\left(\mathrm{cm}^{2}\right)$, leaf dry weight $(\mathrm{mg})$, dry matter yield $(\mathrm{mg})$ and root necrosis (score $=1-5$ ). The last evaluation was based on the rating used by FAECHNER \& BOLTON (1978) in which roots were washed clean of soil and visually examined under a light microscope and rated as follows : 
1. Clean healthy roots.

2. Roots with slight browning and lesions.

3. Roots with brownish, well-defined lesions.

4. Roots with severe lesioning.

5. Dead plants.

A rating of 5 is not recorded in this experiment as plant death could not be exclusively associated with "alfalfa sickness".

\section{RESULTS}

The analysis of variance reveals genotypic differences among the progenies for dry matter yield in the field and plant height and root necrosis in the glasshouse (table 1). In the field, general combining ability variance was significant for all three cuts while the variance for specific combining ability and reciprocal effects were not significant (table 2). Of the traits evaluated on sick soil, only plant height and leaf

TABLE 1

Analysis of variance in two diallel crosses of alfalfa. Analyse de la variance dans deux croisements diallèles de luzerne.

\begin{tabular}{lcc} 
Field diallel (dry matter yield) & \multicolumn{2}{c}{ Mean square values for genotypes } \\
& (d.f. $=71)$ & $\mathrm{F}$ \\
1983 & $17,542^{* *}$ & 1.67 \\
$1984 \mathrm{~A}^{*}$ & $62,145^{* *}$ & 2.53 \\
$1984 \mathrm{~B}$ & $10,758^{* *}$ & 2.24 \\
Glasshouse diallel & $($ d.f. $=35)$ & $\mathrm{F}$ \\
Plant height & $35.8^{*}$ & 1.55 \\
Leaf area & 11,448 & 1.19 \\
Leaf weight & 0.03 & 1.25 \\
Stem weight & 0.14 & 1.44 \\
Total dry weight & 0.34 & 1.31 \\
Root necrosis & $1.36^{* *}$ & 2.76 \\
\hline
\end{tabular}

${ }^{*},{ }^{* *}, \mathrm{~F}$-value significant at $\mathrm{P}=0.05$ at $\mathrm{P}=0.01$, respectively.

${ }^{*} \mathrm{~A}$ and $\mathrm{B}$ refer to the first and second cut of that year, respectively.

TABLE 2

Analysis of variance for the combining ability of nine alfalfa clones in two diallel crosses.

Analyse de la variance pour l'aptitude à la combinaison de neuf clones de luzerne dans deux croisements diallèles.

\begin{tabular}{lcccc}
\hline \multirow{2}{*}{$\begin{array}{l}\text { Field diallel (dry matter } \\
\text { yield) }\end{array}$} & \multicolumn{4}{c}{ Mean square value for genotypes } \\
$\quad$ d.f. & 8 & $\mathrm{~F}$ & S.C.A. & $\mathrm{F}$ \\
1983 & $59,575^{* *}$ & 5.66 & 27 & \\
1984A*** & $283,269^{* *}$ & 2.64 & 123,884 & 1.32 \\
1984B & $64,298^{* *}$ & 3.34 & 24,438 & 1.15 \\
Glasshouse diallel & & & & \\
d.f. & & & & \\
Plant height & 8 & 27 & & \\
Leaf area & $64^{* *}$ & 2.75 & 27.57 & 1.19 \\
Leaf weight & $19,625^{*}$ & 2.03 & 9,026 & 0.94 \\
Stem weight & .58 & 0.98 & 0.79 & 1.32 \\
Total weight & 0.12 & 0.13 & 0.93 & 1.35 \\
Root necrosis & 0.37 & 1.45 & 1.45 & 1.27 \\
& 1.21 & 1.45 & 0.33 & 1.28 \\
\hline \hline
\end{tabular}

$*^{*}, * *, \mathrm{~F}$-value significant at $\mathrm{P}=0.05$ and $\mathrm{P}=0.01$, respectively ${ }^{* * *} \mathrm{~A}$ and $\mathrm{B}$ refer to the first and second cut of that year, respectively.
TABLE 3

General combining ability effects of nine alfalfa clones in two diallel crosses.

Effets de l'aptitude générale à la combinaison de neuf clones de luzerne dans deux croisements diallèles.

\begin{tabular}{|c|c|c|c|c|c|c|}
\hline \multirow{2}{*}{$\begin{array}{l}\text { Parental } \\
\text { clone }\end{array}$} & \multicolumn{6}{|c|}{ General combining ability effects } \\
\hline & 1983 & $1984 \mathrm{~A}$ & 1984B & $1983+4$ & $\begin{array}{l}\text { Plant } \\
\text { height }\end{array}$ & $\begin{array}{l}\text { Leaf } \\
\text { area }\end{array}$ \\
\hline IV9* & 192 & 467 & -21 & 639 & 0.13 & 14.84 \\
\hline $2 \mathrm{G} 169$ & -203 & 342 & 151 & 290 & 0.56 & 2.01 \\
\hline $2 \mathrm{~B} 76$ & 162 & 192 & 134 & 489 & 0.98 & 36.44 \\
\hline $2 \mathrm{~B} 29$ & 19 & -128 & -115 & $-\quad 224$ & -1.59 & -16.07 \\
\hline $1 \mathrm{G} 169$ & -105 & -789 & -302 & -1197 & -0.02 & 7.46 \\
\hline $2 V 13$ & -389 & 14 & -127 & -502 & 1.13 & 16.16 \\
\hline $2 \mathrm{~B} 183$ & 44 & -653 & 54 & $-\quad 555$ & 0.70 & -24.53 \\
\hline 2R187 & 313 & 308 & 263 & 884 & -0.30 & -17.14 \\
\hline Beaver & -34 & 246 & -36 & 176 & -1.59 & -19.18 \\
\hline S.E.*** & 115 & 129 & 97 & 235 & 1.32 & 7.13 \\
\hline
\end{tabular}

* Reference key to clone origins : $\mathrm{V}=$ Vernal ; $\mathrm{G}=\mathrm{Grimm}$; $\mathrm{B}=$ Beaver ; $\mathbf{R}=$ Roamer

** Standard error.

area registered significant general combining ability variances. Specific combining ability and reciprocal variances showed no significant differences. Table 3 presents the combining ability effects of the clones for dry matter yield in the field and plant height and leaf area in the glasshouse. The parents rank in different orders for these three traits. For dry matter yield they rank (in descending order of magnitude) as follows : 2R187, IVP9, 2B76, 2G169, Beaver, 2B29, 2V13, $2 \mathrm{~B} 183$ and $2 \mathrm{G} 169$. The ranking for plant height in the glasshouse is : $2 \mathrm{R} 187,2 \mathrm{~B} 183,2 \mathrm{~B} 29,1 \mathrm{G} 169,2 \mathrm{G} 169$, 2V13, 2B76, 1VP9 and Beaver ; and for leaf area it is : $2 \mathrm{~B} 183,2 \mathrm{R} 187,2 \mathrm{G} 169,2 \mathrm{~V} 13,1 \mathrm{G} 169,1 \mathrm{VP} 9,2 \mathrm{~B} 76$, Beaver and 2B29.

\section{DISCUSSION}

The results from these diallel crosses indicated that, since the clones are of diverse origin, previous selection has led to homogeneity of the clonal material. Of the seven traits evaluated in the glasshouse, genotypic differences among the thirty-six progenies were detected only for plant height and root necrosis (table 1). The general combining ability variance for plant height and leaf area is significant (table 2) but the remaining traits are not, and no significant specific combining ability or reciprocal variances were detected. ADAMS \& SEMENIUK (1958) state that it is possible to deplete additive genetic variance in one cycle of recurrent selection. FAECHNER \& BOLTON (1978) allude to the decreasing additive genetic component of variation for height and root necrosis in the second and third cycles of recurrent selection in this material. Furthermore, their third selection cycle did not give enhanced yield. It can thus be concluded that additive variation for the traits employed in selecting resistant genotypes (increased height, low root necrosis and high yield) has been depleted in this population, and progress to selecting for increased resistance in these stocks using 
the same techniques cannot be expected. This points to either a need for a more efficient selection method or a wider range of genetic variation before further progress in obtaining disease resistance can be made. Additional genetic sources of disease resistance are not known, so a more efficient selection method should be sought. Tissue culture techniques leave shown promise in detecting new variation for disease resistance. However, a concise definition of "alfalfa sickness" would be required and the causal organism determined with certainity if toxins are to be isolated and tissue culture methods are to be used.
Though the initial genetic base of the stocks studied was very wide this study of gene action shows an absence of significant genetic variation for leaf weight, stem weight and total dry weight as determined in the glasshouse. This implies that, in selecting for plant height and root necrosis, there was indirect selection for these traits and their genetic variation was simultaneously reduced.

Reçu le 30 janvier 1986. Accepté le 8 août 1986.

\section{REFERENCES}

Adams M. W. \& Semeniuk G., 1958. The heritability of reaction in alfalfa to common leafspot. Agron. J., 50, 677-679.

Damirgi S. M., Cook F. D. \& Webster G. R., 1976. Alfalfa disease in some Alberta soils. Can. J. Soil Sci., 56, 97-103.

Damirgi S. M., Cook F. D. \& Webster G. R., 1978. Incidence of root rot fungus disease in alfalfa sick soil of central Alberta. Can. J. Soil Sci., 58, 229-236.

Damirgi S. M., Bolton J. L., Webster G. R. \& Cook F. D., 1979. Resistance and susceptibility of selected alfalfa lines to inoculationwith a Phytophthora megasperma isolate. Can. J. Plant Sci., 59, 1153-1154.

Faechner T. R. \& Bolton J. L., 1978. Genetics of resistance and susceptibility in alfalfa to alfalfa sick soil. Can. J. Plant Sci., 58, 945-952.
Goplen B. P. \& Webster G. R., 1969. Selection in Medicago sativa for tolerance to alfalfa sick soils of central Alberta. Agron. J., 61, 589-591.

Griffing, 1956. Concept of general and specific combining ability in relation to diallel crossing systems. Austral. J. Biol. Sci., 9, 463-493.

Jinks J. L. \& Hayman B. I., 1953. The analysis of diallel crosses. Maize Genetics Newsletter, 27, 48-54.

Webster G. R. \& Hawn E. J., 1973. Distribution of Paratylenchus projectus in central and northern Alberta. Can. Plant Dis. Sci., 53, 175-177.

Webster G. R., Khan S. U. \& Moore A. W., 1967. Poor growth of alfalfa (Medicago sativa) on some Alberta Soils. Agron. J., 59, $37-41$. 